University of Nebraska - Lincoln

DigitalCommons@University of Nebraska - Lincoln

Faculty Papers and Publications in Animal

Science

Animal Science Department

March 2001

\title{
Usefulness of subjective ovine milk scores: I. Associations with range ewe characteristics and lamb production
}

\section{G. D. Snowder}

USDA, ARS, U.S. Sheep Experiment Station, Dubois, ID

\section{A.D. Knight}

USDA, ARS, U.S. Sheep Experiment Station, Dubois, ID

L. Dale Van Vleck

University of Nebraska-Lincoln, dvan-vleck1@unl.edu

C. M. Bromley

University of Nebraska-Lincoln

T. R. Kellom

USDA, ARS, U.S. Sheep Experiment Station, Dubois, ID

Follow this and additional works at: https://digitalcommons.unl.edu/animalscifacpub

Part of the Animal Sciences Commons

Snowder, G. D.; Knight, A.D.; Van Vleck, L. Dale; Bromley, C. M.; and Kellom, T. R., "Usefulness of subjective ovine milk scores: I. Associations with range ewe characteristics and lamb production" (2001). Faculty Papers and Publications in Animal Science. 224.

https://digitalcommons.unl.edu/animalscifacpub/224

This Article is brought to you for free and open access by the Animal Science Department at DigitalCommons@University of Nebraska - Lincoln. It has been accepted for inclusion in Faculty Papers and Publications in Animal Science by an authorized administrator of DigitalCommons@University of Nebraska - Lincoln. 


\title{
Usefulness of subjective ovine milk scores: I. Associations with range ewe characteristics and lamb production
}

\author{
G. D. Snowder*,1, A. D. Knight*, L. D. Van Vleck $\dagger$, C. M. Bromley $\neq$, and T. R. Kellom* \\ *USDA, ARS, U.S. Sheep Experiment Station, Dubois, ID 83423; †USDA, ARS, U.S. Meat Animal Research \\ Center, Lincoln, NE 68583; and $\ddagger$ University of Nebraska, Lincoln 68583
}

\begin{abstract}
Range ewes are commonly evaluated for milking ability by producers to determine the ewe's ability to rear lamb(s). The U.S. Sheep Experiment Station has subjectively scored (low, average, high) a ewe's milking ability within $24 \mathrm{~h}$ of lambing for many years. The relationship of subjective milk scores with lamb production was investigated using lambing records of Columbia ( $\mathrm{n}=1,731)$, Polypay $(\mathrm{n}=1,129)$, Rambouillet $(\mathrm{n}=1,704)$, and Targhee $(\mathrm{n}=1,638)$ ewes. The incidence of high milk scores increased from less than $10 \%$ at first parity to 29 to $40 \%$ at second and greater parities. At maturity, Columbia ewes (38\%) had the highest percentage of high milk scores. A positive association existed between ewe BW and her milk score at third and later parities. Ewes with high milk scores gave birth to heavier lambs $(P<0.05)$, whereas ewes with low milk scores were associated with lighter $(P<0.05)$ lambs at birth. Ewes with low milk scores weaned less $(P<0.05)$ total weight than ewes with better milk scores across all age groups for all breeds. Lighter weaned litter weights
\end{abstract}

from ewes with low milk scores were linked to lighter birth weights and fewer weaned lambs. Differences for litter weight weaned between ewes with average and high milk scores were generally observed at 2 and $3 \mathrm{yr}$ of age, when litter weights were heavier among ewes with high milk scores $(P<0.05)$ for all breeds. Between the ages of 1 and $3 \mathrm{yr}$, Columbia, Polypay, Rambouillet, and Targhee ewes with an average milk score weaned heavier $(P<0.05)$ litters (average differences of 10,9 , 13 , and $12 \%$, respectively) than ewes with low milk scores. For all breeds at all ages, individual lamb weaning weights were heavier $(P<0.05)$ when they were reared by ewes with high milk scores compared to lambs reared by ewes with low milk scores. Results suggest that milk score is an economically important trait in these four breeds and should be considered in management and breeding objectives; at a minimum, the incidence of low milk scores should be kept as small as possible.

Key Words: Ewes, Growth, Lactation, Lambs, Management, Milk

(C2001 American Society of Animal Science. All rights reserved.

J. Anim. Sci. 2001. 79:811-818

\section{Introduction}

The significant influence of ewe milk production on preweaning weight gain of their lambs has been clearly defined (Neidig and Iddings, 1919; Burris and Baugus, 1955; Boyazoglu and Treacher, 1978). Increased milk production is associated with increased lamb survival and growth, especially during early lactation (TorresHernandez and Hohenboken, 1980). However, a practical and effective method of measuring milk production in commercial range sheep has not been identified.

For many years at the U. S. Sheep Experiment Station, Dubois, ID, a subjective milk score has been assigned to each ewe within a few hours after lambing.

${ }^{1}$ Correspondence: HC 62, Box 2010 (phone: 208-374-5306; fax: 208374-5582).

Received July 10, 2000.

Accepted December 6, 2000.
This milk score is used as a management tool in making decisions to graft or orphan lambs. Annual milk scores are maintained as a part of each ewe's lifetime production record. Commercial shed lambing operations also typically evaluate ewe milking ability shortly after lambing for management purposes, although only rarely is an attempt made to assign or record a milk production score. The present study investigated the relationship between a ewe's early postpartum milk score and her productivity measured by lamb survival and weight of lamb weaned. If the relationship is sufficiently high, this method of assigning a milk score could easily be adopted by commercial and purebred producers to aid in management decisions and could possibly serve as a selection criterion to improve lamb survival and weaning weight.

\section{Materials and Methods}

Traits Measured and Management. This study used post facto data collected at the U. S. Sheep Experiment 
Station from 1977 to 1988 under management conditions similar to those used in many western range sheep production systems. Lambs were typically born from late March through early May. Ewes with newborn lambs were removed from an outside drop lot and placed inside a covered lambing shed in a $1.5-\mathrm{m}^{2}$ pen, typically for $2 \mathrm{~d}$, before being moved to larger outside mixing pens with other ewe and lamb(s) pairs. Within a few hours of birth, lambs were categorized by their sex, weighed, and ear-tagged. Each ewe was given a milk score (subjectively assigned by the scorer after milking the teats, palpating the udder, and noting the fill of newborn lambs) in the range of 0 to 5 . A 0 indicated a dry or small udder with little or no milk and a 5 indicated a healthy udder producing abundant milk. Almost all milk scores were assigned by the same individual during the study period.

Preliminary statistical analyses showed that milk scores were distributed differently among age of dam groups. This problem was resolved by converting the scale with six codes into three categories of milk production: scores 0 through 2 were converted to "low," score 3 to "average," and scores 4 and 5 to "high." A trimodal scoring system (low, average, and high) may also be more practical for commercial sheep operations than a scale with six codes. Examples of milk scores are depicted in Figure 1.

Milk score was considered by the lambing crew in making decisions about whether lamb(s) should remain with a ewe, be grafted to a different ewe judged to have adequate milk to raise a foster lamb, or, if a foster dam was not available, to be orphaned. Litter size per ewe was always restricted to a maximum of two lambs; therefore, excess lambs were either grafted or orphaned (i.e., no ewe was released from the lambing shed with more than two lambs).

Records were of Rambouillet, Targhee, Columbia, and Polypay ewes ( $1 \mathrm{yr}$ through $5 \mathrm{yr}$ of age) present in selection lines during the period 1977 through 1988 (three lines each of Rambouillets, Targhees, and Columbias and two lines of Polypays, each line maintained at approximately 140 mature ewes and 50 replacement ewe lambs). Genetic lines were described by Ercanbrack and Knight (1998). Only scores on ewes $(\mathrm{n}=6,202)$ giving birth to lambs born alive and receiving a milk score were included in the data set (Table 1).

In early May of each year, lambs were moved with their dams to spring grazing on sagebrush-grass range. Ewes were shorn in mid to late May. In late June, ewes with their lambs were assigned to one of three grazing bands of approximately 1,000 ewes. Bands were separately trailed to mountain summer ranges, where they grazed amid coniferous forests and on high open slopes and meadows at elevations ranging from 2,000 to 2,900 $\mathrm{m}$ during July and August under traditional herded conditions. Weaning data were obtained on the summer range in mid-August when lambs were approximately $120 \mathrm{~d}$ of age. Ewes and lambs were gathered in the early morning (approximately 0600) and confined in a large corral at weaning. Ewes and lambs were identified by ear tag number and weighed individually on a portable electronic scale.

In addition to milk scores and lamb weaning weights, several other ewe production traits were measured to determine their relationship with milk score. Animal size was characterized by BW of the ewe in the spring as measured immediately after shearing. Body weights of ewes were adjusted to a 365-d standard by calculating the average daily difference between consecutive an-
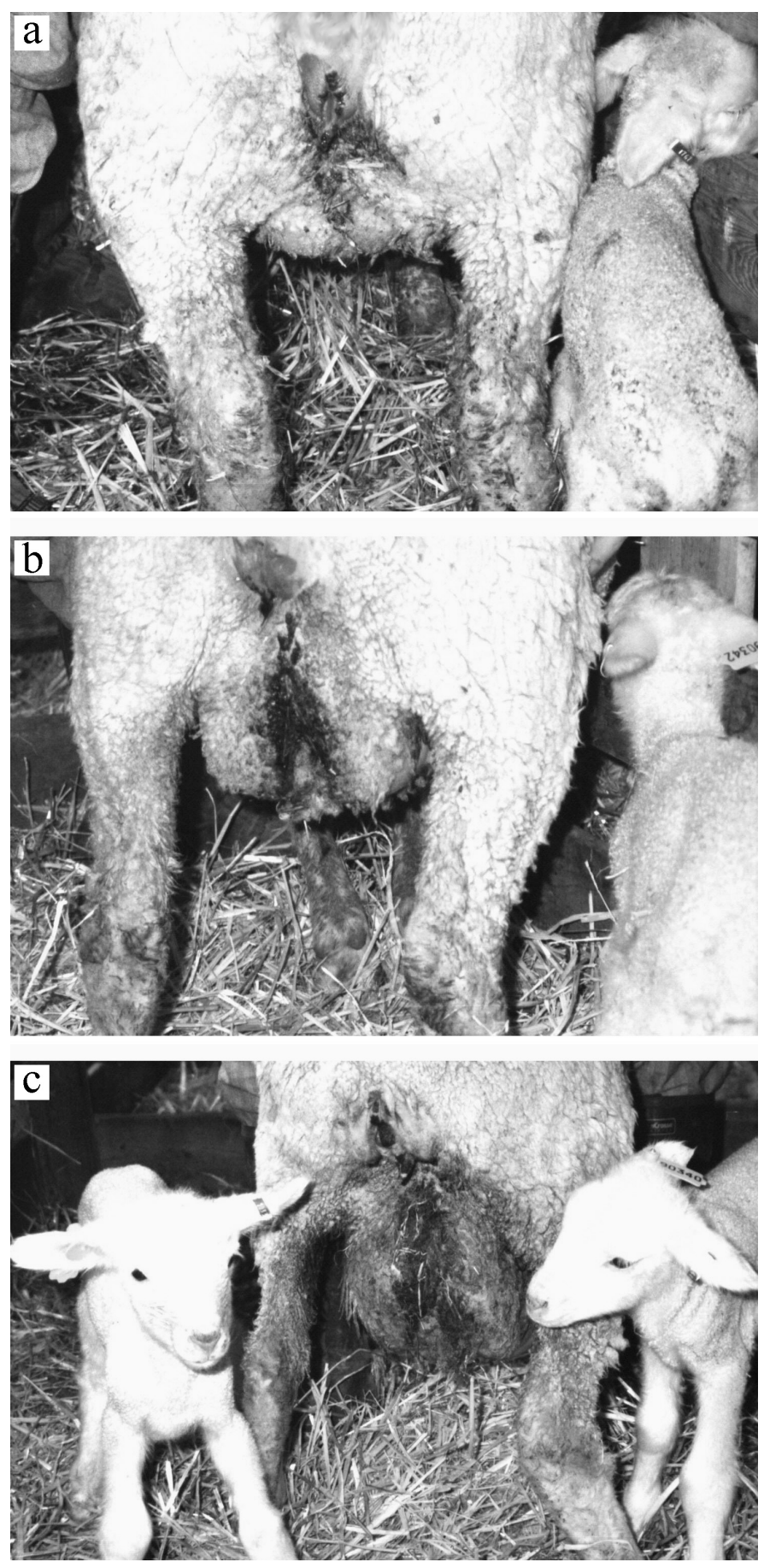

Figure 1. Examples of a) low, b) average, and c) high subjective milk scores. 
Table 1. Number of ewes lambing and live-born lambs by milk score, breed, and age (yr) of dam

\begin{tabular}{|c|c|c|c|c|c|c|}
\hline \multirow{2}{*}{$\begin{array}{l}\text { Breed and } \\
\text { age of dam }\end{array}$} & \multicolumn{3}{|c|}{ Ewes lambing } & \multicolumn{3}{|c|}{ Live-born lambs } \\
\hline & Low $^{\mathrm{a}}$ & $\operatorname{Avg}^{\mathrm{a}}$ & $\operatorname{High}^{\mathrm{a}}$ & Low $^{\mathrm{a}}$ & $\operatorname{Avg}^{\mathrm{a}}$ & High $^{2}$ \\
\hline \multicolumn{7}{|c|}{ Columbia (1,731 total individual ewes) } \\
\hline 1 & 433 & 164 & 10 & 502 & 181 & 11 \\
\hline 2 & 219 & 573 & 259 & 314 & 796 & 379 \\
\hline 3 & 136 & 422 & 328 & 214 & 669 & 532 \\
\hline 4 & 100 & 351 & 259 & 165 & 602 & 424 \\
\hline 5 & 79 & 258 & 224 & 135 & 453 & 369 \\
\hline \multicolumn{7}{|c|}{ Polypay (1,129 total individual ewes) } \\
\hline 1 & 695 & 231 & 5 & 960 & 328 & 8 \\
\hline 2 & 254 & 329 & 58 & 450 & 615 & 115 \\
\hline 3 & 132 & 285 & 117 & 253 & 567 & 235 \\
\hline 4 & 109 & 235 & 92 & 221 & 494 & 193 \\
\hline 5 & 95 & 153 & 85 & 185 & 310 & 177 \\
\hline \multicolumn{7}{|c|}{ Rambouillet (1,704 total individual ewes) } \\
\hline 1 & 811 & 96 & 2 & 906 & 109 & 2 \\
\hline 2 & 452 & 414 & 97 & 628 & 604 & 142 \\
\hline 3 & 223 & 435 & 193 & 365 & 717 & 322 \\
\hline 4 & 151 & 378 & 217 & 266 & 661 & 378 \\
\hline 5 & 106 & 301 & 207 & 187 & 557 & 372 \\
\hline \multicolumn{7}{|c|}{ Targhee (1,638 total individual ewes) } \\
\hline 1 & 627 & 84 & 3 & 676 & 90 & 4 \\
\hline 2 & 395 & 479 & 148 & 516 & 634 & 217 \\
\hline 3 & 219 & 440 & 234 & 329 & 698 & 388 \\
\hline 4 & 120 & 370 & 207 & 199 & 627 & 358 \\
\hline 5 & 106 & 262 & 170 & 178 & 458 & 282 \\
\hline
\end{tabular}

aEwe's milking potential as subjectively measured within $24 \mathrm{~h}$ postpartum.

nual weights and multiplying by 365 . Prolificacy (number of lambs born), number of lambs born alive, number of lambs weaned, and total litter weight weaned were determined for each ewe that lambed. Birth weight was recorded for each lamb born.

Because fostering is known to affect weaning weight of lambs (Snowder and Knight, 1995), grafted lambs, as well as orphaned lambs, were excluded (and their dams if no lamb was raised) from the analyses of traits that were milk-score-dependent: weaning weight, total lambs weaned, and total litter weight weaned. This rule eliminated all lambs born to dams with a milk score of 0 and $35 \%$ of all lambs born to dams with a milk score of 1 . These eliminations permitted an assessment of the effects of milk score on production traits without the bias of other attendant circumstances contributing to a low milk score (i.e., disease or other stress-related problems). Poor milk scores, such as a 0 , are often associated with short-term gestations in ewes less physiologically prepared for lactation and that exhibit less mammary development than full-term gestating ewes (Rattray et al., 1974). Generally, lambs born to shortterm gestating ewes are less viable and have lighter birth weights (LeFeuvre and Jordan, 1979). These factors influence the decision to graft or orphan lambs.

The management system that included evaluating the udder and condition of the lamb(s) and ewe to determine the potential number of lambs a ewe may rear may have imposed a bias. The system increased the probability that the lambs a ewe suckles will survive. Also, because litter size was artificially restricted to a maximum of two lambs, the ability of a ewe with average or high milk scores to rear litters greater than two lambs cannot be examined. Under commercial range production systems, the practice of artificially limiting litter size based on subjective evaluation of the udder and condition of lamb(s) and ewe is common. Because the limitations imposed on this data set are typical of western range production systems, the results may apply only to similar or related production systems.

Statistical Analysis. The distribution of milk scores was not the same for all ages (Table 1) because the size and function of the mammary gland are affected by age and(or) parity. For example, within the breeds studied very few high milk scores were assigned to young ewes. Therefore, the milk score $\times$ age of ewe interaction could not be appropriately statistically tested. Confounding of ewe $\times$ age interaction with year, the fact that not all ewes lamb every year, and that ewes are removed from the flock at different ages did not permit satisfactory statistical analyses of repeated measures. Analyzing the data within age of ewe was deemed a reasonable approach. The maximum age for ewes was limited to 5 yr because numbers within older age groups were small.

The effects of milk score on ewe BW, prolificacy, number of lambs born alive, lamb birth weight, number of lambs weaned, and lamb weaning weight were determined by least squares procedures separately for each 
Table 2. Distribution of milk scores (\%) by breed and age (yr) of ewes with live lambs

\begin{tabular}{|c|c|c|c|c|c|c|c|c|c|c|c|c|}
\hline \multirow[b]{2}{*}{ Age of ewe } & \multicolumn{3}{|c|}{ Columbia } & \multicolumn{3}{|c|}{ Polypay } & \multicolumn{3}{|c|}{ Rambouillet } & \multicolumn{3}{|c|}{ Targhee } \\
\hline & Low & Avg & High & Low & Avg & High & Low & Avg & High & Low & Avg & High \\
\hline 1 & 71.3 & 27.0 & 1.6 & 74.7 & 24.8 & 0.5 & 89.2 & 10.6 & 0.2 & 87.8 & 11.8 & 0.4 \\
\hline 2 & 20.8 & 54.5 & 24.6 & 39.6 & 51.3 & 9.0 & 46.9 & 43.0 & 10.1 & 38.6 & 46.9 & 14.5 \\
\hline 3 & 15.3 & 47.6 & 37.0 & 24.7 & 53.4 & 21.9 & 26.2 & 51.1 & 22.7 & 24.5 & 49.3 & 26.2 \\
\hline 4 & 14.1 & 49.4 & 36.5 & 25.0 & 53.9 & 21.1 & 20.2 & 50.7 & 29.1 & 17.2 & 53.1 & 29.7 \\
\hline 5 & 14.1 & 46.0 & 39.9 & 28.5 & 45.9 & 25.5 & 17.3 & 49.0 & 33.7 & 19.7 & 48.7 & 31.6 \\
\hline Mature $^{\mathrm{a}}$ & 14.5 & 47.7 & 37.8 & 26.1 & 51.1 & 22.8 & 21.2 & 50.3 & 28.5 & 20.5 & 50.46 & 29.2 \\
\hline
\end{tabular}

${ }^{\text {a}}$ Mature is the unweighted average of all ewes older than $2 \mathrm{yr}$ of age.

breed and age of dam group. Harvey's LSMLMW PC2 version (1990) computer program was used, which is appropriate for obtaining generalized least squares results from data characterized by unequal subclass numbers. Fixed effects included milk score (low, average, or high), year (1977 through 1988), genetic line (number of lines varied within breed, range of two to three lines), litter size at birth (one to three), litter size at rearing (single or twin), and sex of lamb (ram, wether, or ewe). Preliminary statistical analyses found primary interactions not to be significant $(P>0.10)$ for every model; therefore, they were not included in final analyses.
The effect of milk score on ewe BW was analyzed with a model that included fixed effects for milk score, genetic line, number of lambs born, and year. The effect of milk score on lamb birth weight was analyzed using the above described model plus the effect of sex of the lamb. Models for prolificacy (number of lambs born per ewe lambing) and percentage of lambs born alive included effects of year, genetic line, and milk score.

Survival of lambs to weaning was based only on lambs born alive without consideration of other factors (e.g., cause of death or age at death). Lamb survival (i.e., live or dead) was modeled with fixed effects for milk score, year, genetic line, sex of lamb, grazing band $(1,2$, or 3$)$

Table 3. Least squares means for ewe BW and individual lamb birth weight by milk score, breed, and age (yr) of dam

\begin{tabular}{|c|c|c|c|c|c|c|c|c|}
\hline \multirow{2}{*}{$\begin{array}{l}\text { Breed and } \\
\text { age of dam }\end{array}$} & \multicolumn{4}{|c|}{ Ewe BW, kg ${ }^{\mathrm{a}}$} & \multicolumn{4}{|c|}{ Lamb birth weight, $\mathrm{kg}$} \\
\hline & Low $^{b}$ & $\mathrm{Avg}^{\mathrm{b}}$ & High $^{b}$ & SE range & Low $^{b}$ & $\mathrm{Avg}^{\mathrm{b}}$ & High $^{\mathrm{b}}$ & SE range \\
\hline \multicolumn{9}{|l|}{ Columbia } \\
\hline 1 & 59.5 & 61.2 & $\mathrm{ND}^{\mathrm{c}}$ & $1.3-1.6$ & $3.9^{\mathrm{g}}$ & $4.3^{\mathrm{h}}$ & ND & $0.1-0.3$ \\
\hline 2 & $62.9^{\mathrm{d}}$ & $63.2^{\mathrm{d}}$ & $65.2^{\mathrm{e}}$ & $0.3-0.5$ & $4.7^{\mathrm{g}}$ & $4.9^{\mathrm{h}}$ & $5.1^{\mathrm{i}}$ & 0.1 \\
\hline 3 & 69.0 & 68.4 & 69.0 & $0.3-0.7$ & $4.8^{\mathrm{g}}$ & $5.0^{\mathrm{gh}}$ & $5.1^{\mathrm{h}}$ & 0.1 \\
\hline 4 & 71.0 & 71.4 & 71.8 & $0.4-0.9$ & $4.7^{\mathrm{g}}$ & $5.0^{\mathrm{h}}$ & $5.2^{\mathrm{i}}$ & 0.1 \\
\hline 5 & $68.9^{\mathrm{d}}$ & $72.8^{\mathrm{e}}$ & $72.9^{\mathrm{e}}$ & $0.5-1.0$ & $4.9^{\mathrm{g}}$ & $5.2^{\mathrm{h}}$ & $5.4^{\mathrm{i}}$ & 0.1 \\
\hline \multicolumn{9}{|l|}{ Polypay } \\
\hline 1 & 52.0 & 53.3 & 52.6 & $0.4-0.6$ & $3.6^{\mathrm{g}}$ & $3.8^{\mathrm{h}}$ & ND & 0.1 \\
\hline 2 & 59.5 & 59.4 & 59.1 & $0.3-0.7$ & $3.9^{g}$ & $4.1^{\mathrm{h}}$ & $4.1^{\mathrm{h}}$ & 0.1 \\
\hline 3 & $63.5^{\mathrm{d}}$ & $64.6^{\mathrm{de}}$ & $65.6^{\mathrm{e}}$ & $0.5-0.6$ & $4.2^{\mathrm{g}}$ & $4.5^{\mathrm{h}}$ & $4.5^{\mathrm{h}}$ & 0.1 \\
\hline 4 & $66.0^{\mathrm{de}}$ & $65.5^{\mathrm{d}}$ & $67.5^{\mathrm{e}}$ & $0.6-0.8$ & $4.2^{\mathrm{g}}$ & $4.4^{\mathrm{h}}$ & $4.6^{\mathrm{i}}$ & 0.1 \\
\hline 5 & $63.9^{\mathrm{d}}$ & $65.9^{\mathrm{e}}$ & $68.1^{\mathrm{f}}$ & $0.7-0.8$ & $4.0^{\mathrm{g}}$ & $4.3^{\mathrm{h}}$ & $4.5^{\mathrm{i}}$ & 0.1 \\
\hline \multicolumn{9}{|l|}{ Rambouillet } \\
\hline 1 & 52.7 & 52.1 & ND & $1.3-1.8$ & $4.1^{\mathrm{g}}$ & $4.5^{\mathrm{h}}$ & ND & 0.1 \\
\hline 2 & 60.1 & 59.3 & 60.4 & $0.3-0.6$ & $4.4^{\mathrm{g}}$ & $4.7^{\mathrm{h}}$ & $4.7^{\mathrm{h}}$ & 0.1 \\
\hline 3 & $64.4^{\mathrm{d}}$ & $64.9^{\mathrm{de}}$ & $65.9^{\mathrm{e}}$ & $0.3-0.5$ & $4.7^{\mathrm{g}}$ & $4.9^{\mathrm{h}}$ & $4.9^{\mathrm{h}}$ & 0.1 \\
\hline 4 & 66.6 & 66.9 & 67.0 & $0.4-0.6$ & $4.7^{\mathrm{g}}$ & $5.0^{\mathrm{h}}$ & $5.1^{\mathrm{h}}$ & 0.1 \\
\hline 5 & $66.4^{\mathrm{d}}$ & $67.5^{\mathrm{de}}$ & $68.2^{\mathrm{e}}$ & $0.4-0.7$ & $4.7^{\mathrm{g}}$ & $5.0^{\mathrm{h}}$ & $5.2^{\mathrm{i}}$ & 0.1 \\
\hline \multicolumn{9}{|l|}{ Targhee } \\
\hline 1 & 57.2 & 56.9 & ND & $1.9-2.7$ & $4.0^{\mathrm{g}}$ & $4.5^{\mathrm{h}}$ & ND & 0.1 \\
\hline 2 & $60.7^{\mathrm{d}}$ & $60.5^{\mathrm{d}}$ & $62.0^{\mathrm{e}}$ & $0.3-0.6$ & $4.5^{\mathrm{g}}$ & $4.8^{\mathrm{h}}$ & $4.9^{\mathrm{h}}$ & 0.1 \\
\hline 3 & 65.3 & 65.5 & 65.4 & $0.4-0.5$ & $4.7^{\mathrm{g}}$ & $4.9^{\mathrm{h}}$ & $5.2^{\mathrm{i}}$ & 0.1 \\
\hline 4 & $66.7^{\mathrm{d}}$ & $67.9^{\mathrm{de}}$ & $68.9^{\mathrm{e}}$ & $0.4-0.7$ & $4.8^{\mathrm{g}}$ & $5.1^{\mathrm{h}}$ & $5.1^{\mathrm{h}}$ & 0.1 \\
\hline 5 & $67.2^{\mathrm{d}}$ & $68.6^{\mathrm{de}}$ & $69.5^{\mathrm{e}}$ & $0.5-0.9$ & $4.8^{\mathrm{g}}$ & $5.1^{\mathrm{h}}$ & $5.1^{\mathrm{h}}$ & 0.1 \\
\hline
\end{tabular}


and type of rearing (single or twin). The model for number of lambs weaned per ewe lambing included fixed effects for year, genetic line, milk score, and grazing band.

Individual lamb weaning weights were analyzed with a model that included fixed effects of milk score, grazing band, year, type of birth and rearing code (11, 21, 22, 31 , or $32 ; 21$ denotes a lamb born a twin and reared as a single, etc.), genetic line, and sex of lamb. Age of lamb (d) at weaning was a covariate.

Total litter weight weaned was the sum of adjusted individual lamb weights at weaning for the ewe. Individual lamb weights were preadjusted to $120 \mathrm{~d}$ of age for fixed effects of grazing band, sex of lamb, and a covariate for Julian day of birth. No correction was made initially for age of dam and type of birth and rearing because these factors are known to affect ewe milk production (Slen et al., 1963; Torres-Hernandez and Hohenboken, 1980; Snowder and Glimp, 1991); these effects were included in the adjustment model so that their effects would be accounted for. The effect of milk score on total litter weight weaned was analyzed with a model that included fixed effects of milk score, year, type of rearing (single or multiple), and genetic line. Tests of linear contrasts of differences among least squares means by milk score category were performed within a breed by age or parity groups. Significance was defined at the 0.05 level.

\section{Results and Discussion}

Besides the effects of milk score, most of the other fixed effects (year and number of lambs born or reared) were generally significant for all reproductive and BW traits analyzed. The effects of selection lines, however, were not generally significant but were always included in each model. These effects will not be discussed in detail except where relevant for the biological interpretation of the data related to milk score. No interactions were significant.

Milk Score Distribution. Milk scores were not distributed equally within or across age groups (Table 2). For yearling ewes, milk score was generally characterized as low (71 to $89 \%$ ). Few yearling ewes were characterized with a high milk score $(0.2$ to $1.6 \%)$. At age $2 \mathrm{yr}$, milk scores improved, and 43 to $55 \%$ of the ewes were evaluated as average and 21 to $47 \%$ as low. At older ages (3 yr and older), the distribution of milk scores was similar across age groups and breeds; approximately $50 \%$ of the ewes were scored as average, 14 to $29 \%$ as low, and 21 to $40 \%$ as high milk producers.

As yearlings, Rambouillets and Targhees had the highest percentage of low milk scores (89 and $88 \%$,

Table 4. Least squares means for prolificacy and lambs born alive by milk score, breed, and age (yr) of dam

\begin{tabular}{|c|c|c|c|c|c|c|c|c|}
\hline \multirow{2}{*}{$\begin{array}{l}\text { Breed and age } \\
\text { of dam }\end{array}$} & \multicolumn{4}{|c|}{ Prolificacy, \% } & \multicolumn{4}{|c|}{ Lambs born alive, $\%$} \\
\hline & Low $^{\mathrm{a}}$ & Avg $^{\mathrm{a}}$ & High $^{\mathrm{a}}$ & SE range & Low $^{\mathrm{a}}$ & Avg $^{\mathrm{a}}$ & $\operatorname{High}^{\mathrm{a}}$ & SE range \\
\hline \multicolumn{9}{|l|}{ Columbia } \\
\hline 1 & 114.0 & 112.1 & $\mathrm{ND}^{\mathrm{b}}$ & $2.0-3.0$ & $81.1^{\mathrm{e}}$ & $93.1^{\mathrm{f}}$ & ND & $1.8-2.7$ \\
\hline 2 & 141.0 & 141.7 & 147.1 & $2.0-3.1$ & $78.2^{\mathrm{e}}$ & $93.7^{\mathrm{f}}$ & $97.8^{f}$ & $0.9-1.4$ \\
\hline 3 & 159.9 & 162.6 & 160.8 & $2.5-3.7$ & $76.5^{\mathrm{e}}$ & $94.0^{\mathrm{f}}$ & $97.1^{\mathrm{f}}$ & $0.9-1.4$ \\
\hline 4 & $160.8^{\mathrm{c}}$ & $175.5^{\mathrm{d}}$ & $169.1^{\mathrm{cd}}$ & $2.8-4.5$ & $80.6^{\mathrm{e}}$ & $94.4^{\mathrm{f}}$ & $94.6^{f}$ & $1.0-1.7$ \\
\hline 5 & 172.5 & 172.4 & 172.3 & $4.0-6.3$ & $84.0^{\mathrm{e}}$ & $97.1^{\mathrm{f}}$ & $96.9^{f}$ & $1.0-1.6$ \\
\hline \multicolumn{9}{|l|}{ Polypay } \\
\hline 1 & 137.5 & 144.0 & ND & $1.8-3.3$ & $84.9^{\mathrm{e}}$ & $94.4^{\mathrm{f}}$ & ND & $0.9-1.7$ \\
\hline 2 & $180.7^{\mathrm{c}}$ & $190.4^{\mathrm{d}}$ & $188.8^{\mathrm{d}}$ & $3.0-7.1$ & $87.1^{\mathrm{e}}$ & $94.0^{\mathrm{f}}$ & $98.3^{\mathrm{f}}$ & $1.0-2.5$ \\
\hline 3 & 196.8 & 204.2 & 206.8 & $3.7-5.6$ & $90.7^{\mathrm{e}}$ & $96.3^{\mathrm{f}}$ & $97.1^{\mathrm{f}}$ & $0.9-1.4$ \\
\hline 4 & 204.0 & 213.5 & 210.5 & $4.3-6.0$ & 96.5 & 97.7 & 97.3 & $0.8-1.2$ \\
\hline 5 & 201.6 & 212.7 & 216.1 & $5.4-7.7$ & $91.2^{\mathrm{e}}$ & $94.8^{\mathrm{ef}}$ & $96.6^{f}$ & $1.3-1.8$ \\
\hline \multicolumn{9}{|l|}{ Rambouillet } \\
\hline 1 & 110.9 & 109.9 & ND & $1.2-3.4$ & $85.6^{\mathrm{e}}$ & $96.6^{\mathrm{f}}$ & ND & $1.1-3.0$ \\
\hline 2 & $140.2^{\mathrm{c}}$ & $147.1^{\mathrm{d}}$ & $152.1^{\mathrm{d}}$ & $2.1-5.1$ & $85.8^{\mathrm{e}}$ & $94.5^{\mathrm{f}}$ & $98.5^{f}$ & $0.9-2.3$ \\
\hline 3 & $162.3^{\mathrm{c}}$ & $166.0^{\mathrm{cd}}$ & $171.8^{\mathrm{d}}$ & $2.4-3.8$ & $84.8^{\mathrm{e}}$ & $95.0^{\mathrm{f}}$ & $97.3^{f}$ & $0.9-1.4$ \\
\hline 4 & 174.1 & 176.7 & 177.7 & $2.7-4.1$ & $89.0^{\mathrm{e}}$ & $96.4^{\mathrm{f}}$ & $96.4^{\mathrm{f}}$ & $0.7-1.1$ \\
\hline 5 & 177.2 & 186.1 & 183.8 & $3.0-4.9$ & $88.1^{\mathrm{e}}$ & $96.9^{f}$ & $97.1^{\mathrm{f}}$ & $0.7-1.2$ \\
\hline \multicolumn{9}{|l|}{ Targhee } \\
\hline 1 & 107.0 & 105.8 & ND & $1.4-3.2$ & $88.5^{\mathrm{e}}$ & $97.1^{\mathrm{f}}$ & ND & $1.4-3.1$ \\
\hline 2 & $132.3^{\mathrm{c}}$ & $134.8^{\mathrm{c}}$ & $144.0^{\mathrm{d}}$ & $2.1-4.0$ & $89.0^{\mathrm{e}}$ & $94.3^{\mathrm{f}}$ & $98.0^{\mathrm{g}}$ & $0.9-1.0$ \\
\hline 3 & $152.8^{\mathrm{c}}$ & $158.9^{\mathrm{cd}}$ & $165.5^{\mathrm{d}}$ & $2.4-3.3$ & $85.6^{\mathrm{e}}$ & $95.9^{f}$ & $97.0^{f}$ & $0.8-1.2$ \\
\hline 4 & 168.9 & 171.5 & 172.7 & $2.6-4.5$ & $88.2^{\mathrm{e}}$ & $96.6^{\mathrm{f}}$ & $97.3^{\mathrm{f}}$ & $0.8-1.3$ \\
\hline 5 & 171.5 & 176.0 & 168.8 & $3.2-4.9$ & $84.3^{\mathrm{e}}$ & $97.0^{\mathrm{f}}$ & $97.1^{\mathrm{f}}$ & $1.0-1.5$ \\
\hline
\end{tabular}

aEwe's milking potential as subjectively measured within $24 \mathrm{~h}$ postpartum.

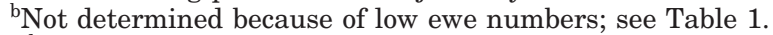

${ }^{c, d}$ Within a row, means for prolificacy without a common superscript letter differ $(P<0.05)$.

e,f,g Within a row, means for lambs born alive without a common superscript letter differ $(P<0.05)$. 
respectively) compared to Columbias and Polypays (71 and $75 \%$, respectively). As mature ewes, Columbias had the highest percentage of high milk scores (38\%) compared to the other breeds (23 to 29\%). The larger percentage of high milk scores among Columbia ewes may be true only in early lactation, because a previous study by Snowder and Glimp (1991) found no differences in milk production among Columbia, Polypay, and Rambouillet ewes from 28 to $84 \mathrm{~d}$ postpartum. Differences in milking ability among other non-dairy sheep breeds during early lactation ( 1 to $8 \mathrm{wk}$ ) have been documented (Slen et al., 1963).

Association of Milk Score with Ewe and Lamb Traits. Associative differences in ewe BW, prolificacy, percentage of lambs born alive, lamb birth weights, and lamb survival to weaning age due to milk score categories were examined (Tables 3, 4, 5, 6, and 7).

Milk score may be positively related to a ewe's BW (Table 3). At 1 and 2 yr of age, ewe BW did not differ $(P>0.05)$ across milk score categories except for 2-yrold Columbia and Targhee ewes, among which ewes with high milk scores were heavier than ewes with average or low milk scores $(P<0.05)$. At older ages, ewes with high milk scores generally weighed more $(P$ $<0.05$ ) than ewes with low milk scores. Heavier BW have been previously associated with ewes of better condition and higher milking capability (Peart, 1968; Gibb and Treacher, 1982). Although the ewes in the present study were given ad libitum access to feed sources, the level of nutrition can also affect ewe milk production (Treacher, 1983).

For all breeds, ewes with low milk scores gave birth to lambs with lighter birth weights than ewes with average or high milk scores $(P<0.05$; Table 3$)$. Birth weights of lambs born to ewes with average milk scores were intermediate. The heaviest birth weights $(P<$ 0.05 ) tended to be associated with ewes with high milk scores, especially for mature Polypays. The lighter lamb birth weights from ewes with low milk scores are a concern because lamb mortality is negatively correlated with lamb birth weight (mortality rate increases as birth weight decreases; Walker and Hunt, 1980). Our data suggest that a contributing cause to higher mortality rates among lambs with lighter birth weights may be an association with the dam's low milking performance.

Ewe prolificacy was not generally associated with subsequent milk score (Table 4). The few significant differences in prolificacy associated with milk score within age groups were randomly distributed, except that 2- and 3-yr-old Rambouillet and Targhee ewes with low milk scores exhibited lower $(P<0.05)$ prolificacy compared to ewes with high milk scores. Increased size and subsequent function of the mammary gland during the last trimester of gestation have been associated with number of fetuses. Delouis et al. (1980) reported that as the number of fetuses increases there is an accompanying increase in placental size, resulting in elevated levels of placental estrogen and lactogen enhancing mammary gland development.
Table 5. Least square means for lamb survival (\%) to weaning at $120 \mathrm{~d}$ of age by milk score, breed, and age (yr) of dam

\begin{tabular}{llllc}
\hline \hline Breed and age & Low $^{\mathrm{a}}$ & Avg $^{\mathrm{a}}$ & High $^{\mathrm{a}}$ & SE range \\
\hline Columbia & & & & \\
1 & 79 & 76 & $\mathrm{ND}^{\mathrm{b}}$ & $3-5$ \\
2 & 88 & 87 & $88^{\mathrm{d}}$ & $2-3$ \\
3 & $79^{\mathrm{c}}$ & $87^{\mathrm{d}}$ & $90^{\mathrm{d}}$ & $2-4$ \\
4 & 93 & 93 & 91 & $3-4$ \\
5 & 88 & 93 & 90 & $2-4$ \\
Polypay & & & & \\
1 & 83 & 82 & $\mathrm{ND}$ & $1-2$ \\
2 & 76 & 78 & 81 & $3-6$ \\
3 & 86 & 87 & 89 & $3-4$ \\
4 & 95 & 93 & 94 & $3-4$ \\
5 & $82^{\mathrm{c}}$ & $93^{\mathrm{d}}$ & $94^{\mathrm{d}}$ & $2-5$ \\
Rambouillet & & & & \\
1 & 82 & 88 & $\mathrm{ND}$ & 2 \\
2 & 81 & 82 & 88 & $1-3$ \\
3 & 75 & 77 & 78 & $3-4$ \\
4 & 93 & 91 & 92 & $2-3$ \\
5 & 87 & 92 & 93 & $1-2$ \\
Targhee & & & & \\
1 & 82 & 85 & ND & $1-4$ \\
2 & 87 & 87 & 88 & $2-3$ \\
3 & 76 & 82 & 82 & $2-3$ \\
4 & 85 & 89 & 88 & 4 \\
5 & $72^{\mathrm{c}}$ & $79^{\mathrm{d}}$ & $87^{\mathrm{e}}$ & $2-3$ \\
\hline
\end{tabular}

aEwe's milking potential subjectively measured within $24 \mathrm{~h}$ postpartum.

${ }^{b}$ Not determined because of low ewe numbers.

${ }_{\mathrm{c}, \mathrm{d}, \mathrm{e}}$ Within a row, means without a common superscript letter differ $(P<0.05)$.

Percentage of live-born lambs (Table 4) reflected the same trend as birth weight and was clearly associated with milk score. The percentage of live-born lambs was generally less $(P<0.05)$ among ewes with low milk scores than among ewes with average or high milk scores. However, this trend was less evident among Polypay ewes 3 yr of age and older, for which the percentage of live-born lambs born to ewes with low milk scores tended to be higher than for other breeds. The higher survival of Polypay lambs may be related to its original genetic background of one-quarter Finnsheep. Previous studies have shown that lambs with varying degrees of Finnsheep breeding had a higher percentage of being born alive and higher survival to weaning than purebred and other crossbred lambs (Snowder et al., 1986; Iman and Slyter, 1996). Also, Gama et al. (1991) reported that Finnsheep crossbred lambs have a better probability of survival than lambs of most other breeds when the effect of litter size is statistically removed.

Survival of live born lambs to weaning age $(120 \mathrm{~d})$ was not strongly associated with improved milk scores (Table 5). Survival rates of lambs reared by ewes with low milk scores from birth to weaning did not generally differ from those of lambs reared by ewes with average or high milk scores. Statistically lower survival rates of lambs reared by ewes with low milk scores were observed only for 5-yr-old Polypay and Targhee ewes 
and 3-yr-old Columbia ewes $(P<0.05)$. The lack of statistical differences in lamb survival rates among milk score groups may not suggest that milk score is unimportant to lamb survival, but rather that the management imposed on this data set by grafting or orphaning lambs from ewes with low milk scores was successful. The objective of the grafting and orphaning process was to give all lambs an equal opportunity for survival to weaning. Commercial producers may be able to increase lamb survival by appraising milk score and lamb vitality.

Ewes with low milk scores weaned fewer lambs at approximately $120 \mathrm{~d}$ of age than ewes with average or high milk scores $(P<0.05$; Table 6$)$. This difference is obviously biased by the management system that purposefully restricted the number of lambs a ewe with a low milk score was allowed to rear under range conditions. The differences in the number of lambs weaned between ewes with average or high milk scores were small $(P>0.05)$. This result indicates that lambing shed crews were effective in identifying which lambs could survive to weaning by remaining with their dams within average and high milk score groups. Although the management practice of fostering lambs from ewes subjectively evaluated as incapable of raising an extra lamb may have biased the estimate of the underlying association between milk score and lamb survival, the management represented normal production practices.

Total litter weight weaned was influenced by the ewe's milk score (Table 6). Ewes with low milk scores weaned less total weight than ewes with better milk scores across all age groups for all breeds $(P<0.05)$. Lighter litter weights from ewes with low milk scores were also linked to lighter birth weights and fewer weaned lambs. At 2 and $3 \mathrm{yr}$ of age, Columbia and Polypay ewes with high milk scores weaned heavier $(P<0.05)$ total litter weights compared to ewes with average milk scores. Ewes with average milk scores weaned heavier $(P<0.05)$ litters (average differences of $10,9,13$, and $12 \%$, respectively) than ewes with low milk scores within each breed and age group. This result suggests that milk score in these four breeds is an economically important trait and should be considered in breeding and management objectives, at least to the extent that the incidence of low milk scores should be kept to a minimum.

Further support for the economic importance of milk score was the strong association between ewe milk score and individual lamb weaning weight within each ewe age group (Table 7). Differences in individual lamb weaning weights according to milk score by age groups indicate a direct relationship between ewe milk score

Table 6. Least squares means for number of lambs weaned and total litter weight weaned per ewe lambing by milk score, breed, and age (yr) of dam

\begin{tabular}{|c|c|c|c|c|c|c|c|c|}
\hline \multirow{2}{*}{$\begin{array}{l}\text { Breed and age } \\
\text { of dam }\end{array}$} & \multicolumn{4}{|c|}{ Lambs weaned } & \multicolumn{4}{|c|}{ Litter weight, kg } \\
\hline & Low $^{\mathrm{a}}$ & $\operatorname{Avg}^{\mathrm{a}}$ & High $^{\mathrm{a}}$ & SE range & Low $^{a}$ & Avg $^{\mathrm{a}}$ & $\operatorname{High}^{\mathrm{a}}$ & SE range \\
\hline \multicolumn{9}{|l|}{ Columbia } \\
\hline 1 & 1.01 & 1.03 & $\mathrm{ND}^{\mathrm{b}}$ & $0.01-0.05$ & $32.5^{f}$ & $34.5^{\mathrm{g}}$ & ND & $0.44-0.60$ \\
\hline 2 & $1.14^{\mathrm{c}}$ & $1.27^{\mathrm{d}}$ & $1.27^{\mathrm{d}}$ & $0.02-0.03$ & $40.5^{\mathrm{f}}$ & $45.1^{\mathrm{g}}$ & $47.3^{\mathrm{h}}$ & $0.53-0.86$ \\
\hline 3 & $1.21^{\mathrm{c}}$ & $1.41^{\mathrm{d}}$ & $1.48^{\mathrm{d}}$ & $0.03-0.05$ & $42.4^{\mathrm{f}}$ & $48.8^{\mathrm{g}}$ & $51.4^{\mathrm{h}}$ & $0.70-1.27$ \\
\hline 4 & $1.23^{\mathrm{c}}$ & $1.52^{\mathrm{d}}$ & $1.43^{\mathrm{d}}$ & $0.03-0.05$ & $43.0^{\mathrm{f}}$ & $51.3^{\mathrm{g}}$ & $49.9^{g}$ & $0.79-1.48$ \\
\hline 5 & $1.21^{\mathrm{c}}$ & $1.55^{\mathrm{d}}$ & $1.47^{\mathrm{d}}$ & $0.03-0.06$ & $41.5^{\mathrm{f}}$ & $52.3^{\mathrm{g}}$ & $52.7^{\mathrm{g}}$ & $0.94-1.80$ \\
\hline \multicolumn{9}{|l|}{ Polypay } \\
\hline 1 & $1.13^{\mathrm{c}}$ & $1.26^{\mathrm{d}}$ & ND & $0.02-0.03$ & $35.2^{\mathrm{f}}$ & $39.2^{\mathrm{g}}$ & ND & $0.39-0.66$ \\
\hline 2 & $1.47^{\mathrm{c}}$ & $1.55^{\mathrm{d}}$ & $1.70^{\mathrm{e}}$ & $0.03-0.07$ & $47.9^{f}$ & $51.1^{\mathrm{g}}$ & $57.0^{\mathrm{h}}$ & $0.87-2.08$ \\
\hline 3 & $1.51^{\mathrm{c}}$ & $1.69^{\mathrm{d}}$ & $1.75^{\mathrm{d}}$ & $0.03-0.05$ & $49.3^{f}$ & $54.5^{\mathrm{g}}$ & $58.1^{\mathrm{h}}$ & $0.99-1.47$ \\
\hline 4 & $1.47^{\mathrm{c}}$ & $1.76^{\mathrm{d}}$ & $1.75^{\mathrm{d}}$ & $0.03-0.05$ & $47.1^{\mathrm{f}}$ & $56.7^{\mathrm{g}}$ & $58.1^{\mathrm{g}}$ & $0.98-1.50$ \\
\hline 5 & $1.43^{\mathrm{c}}$ & $1.71^{\mathrm{d}}$ & $1.71^{\mathrm{d}}$ & $0.04-0.06$ & $45.2^{\mathrm{f}}$ & $55.9^{\mathrm{g}}$ & $56.7^{\mathrm{g}}$ & $1.25-1.75$ \\
\hline \multicolumn{9}{|l|}{ Rambouillet } \\
\hline 1 & $1.01^{\mathrm{c}}$ & $1.08^{\mathrm{d}}$ & ND & $0.01-0.02$ & $31.3^{\mathrm{f}}$ & $34.4^{\mathrm{g}}$ & ND & $0.24-0.57$ \\
\hline 2 & $1.15^{\mathrm{c}}$ & $1.32^{\mathrm{d}}$ & $1.40^{\mathrm{d}}$ & $0.02-0.05$ & $37.9^{f}$ & $43.4^{\mathrm{g}}$ & $46.5^{\mathrm{h}}$ & $0.55-1.24$ \\
\hline 3 & $1.25^{\mathrm{c}}$ & $1.47^{\mathrm{d}}$ & $1.45^{\mathrm{d}}$ & $0.02-0.04$ & $39.3^{f}$ & $46.9^{g}$ & $46.9^{g}$ & $0.63-0.99$ \\
\hline 4 & $1.32^{\mathrm{c}}$ & $1.50^{\mathrm{d}}$ & $1.62^{\mathrm{e}}$ & $0.03-0.04$ & $41.1^{\mathrm{f}}$ & $47.2^{\mathrm{g}}$ & $50.8^{\mathrm{h}}$ & $0.68-1.16$ \\
\hline 5 & $1.24^{\mathrm{c}}$ & $1.58^{\mathrm{d}}$ & $1.61^{\mathrm{d}}$ & $0.02-0.05$ & $38.8^{f}$ & $48.6^{\mathrm{g}}$ & $50.9^{g}$ & $0.78-1.42$ \\
\hline \multicolumn{9}{|l|}{ Targhee } \\
\hline 1 & 1.00 & 1.04 & ND & $0.01-0.01$ & $30.9^{f}$ & $32.7^{\mathrm{g}}$ & ND & $0.31-0.60$ \\
\hline 2 & $1.06^{\mathrm{c}}$ & $1.21^{\mathrm{d}}$ & $1.29^{\mathrm{e}}$ & $0.02-0.03$ & $36.6^{\mathrm{f}}$ & $41.4^{\mathrm{g}}$ & $44.2^{\mathrm{g}}$ & $0.50-0.94$ \\
\hline 3 & $1.20^{\mathrm{c}}$ & $1.43^{\mathrm{d}}$ & $1.48^{\mathrm{d}}$ & $0.02-0.04$ & $38.7^{f}$ & $46.3^{\mathrm{g}}$ & $48.7^{\mathrm{g}}$ & $0.65-0.95$ \\
\hline 4 & $1.31^{\mathrm{c}}$ & $1.52^{\mathrm{d}}$ & $1.49^{\mathrm{d}}$ & $0.03-0.05$ & $42.4^{\mathrm{f}}$ & $48.9^{g}$ & $47.6^{\mathrm{g}}$ & $0.75-1.36$ \\
\hline 5 & $1.16^{\mathrm{c}}$ & $1.48^{\mathrm{d}}$ & $1.45^{\mathrm{d}}$ & $0.03-0.06$ & $38.1^{\mathrm{f}}$ & $47.5^{\mathrm{g}}$ & $47.6^{\mathrm{g}}$ & $0.85-1.55$ \\
\hline
\end{tabular}

aEwe's milking potential subjectively measured within $24 \mathrm{~h}$ postpartum.

${ }^{\mathrm{b}}$ Not determined because of low cell count numbers; see Table 1.

c,d,eWithin a row, means for lambs weaned without a common superscript letter differ $(P<0.05)$.

${ }_{\mathrm{f}, \mathrm{g}, \mathrm{h}}$ Within a row, means for litter weight without a common superscript letter differ $(P<0.05)$. 
Table 7. Least squares means for individual lamb weaning weights $(\mathrm{kg})$ by milk score, breed, and age (yr) of dam

\begin{tabular}{|c|c|c|c|c|}
\hline $\begin{array}{l}\text { Breed and age } \\
\text { of dam }\end{array}$ & Low $^{\mathrm{a}}$ & $\mathrm{Avg}^{\mathrm{a}}$ & $\operatorname{High}^{\mathrm{a}}$ & SE range \\
\hline \multicolumn{5}{|l|}{ Columbia } \\
\hline 1 & $31.1^{\mathrm{c}}$ & $33.0^{\mathrm{d}}$ & $\mathrm{ND}^{\mathrm{b}}$ & $0.23-0.36$ \\
\hline 2 & $33.2^{\mathrm{c}}$ & $33.9^{c}$ & $35.5^{\mathrm{d}}$ & $0.24-0.36$ \\
\hline 3 & $34.8^{\mathrm{c}}$ & $36.1^{\mathrm{d}}$ & $37.0^{\mathrm{e}}$ & $0.26-0.49$ \\
\hline 4 & $36.0^{\mathrm{c}}$ & $36.8^{\mathrm{c}}$ & $38.0^{\mathrm{d}}$ & $0.19-0.39$ \\
\hline 5 & $36.3^{\mathrm{c}}$ & $36.6^{\mathrm{c}}$ & $38.2^{\mathrm{d}}$ & $0.32-0.65$ \\
\hline \multicolumn{5}{|l|}{ Polypay } \\
\hline 1 & $30.4^{\mathrm{c}}$ & $31.4^{\mathrm{c}}$ & ND & $0.18-0.28$ \\
\hline 2 & $32.3^{\mathrm{c}}$ & $32.8^{\text {cd }}$ & $33.5^{\mathrm{d}}$ & $0.26-0.51$ \\
\hline 3 & $33.6^{\mathrm{c}}$ & $33.6^{\mathrm{c}}$ & $34.7^{\mathrm{d}}$ & $0.30-0.39$ \\
\hline 4 & $33.2^{\mathrm{c}}$ & $34.3^{\mathrm{d}}$ & $35.1^{\mathrm{e}}$ & $0.33-0.43$ \\
\hline 5 & $33.4^{\mathrm{c}}$ & $35.4^{\mathrm{d}}$ & $36.5^{\mathrm{e}}$ & $0.40-0.49$ \\
\hline \multicolumn{5}{|l|}{ Rambouillet } \\
\hline 1 & 29.0 & 31.2 & ND & $0.60-0.83$ \\
\hline 2 & $30.5^{\mathrm{c}}$ & $32.2^{\mathrm{d}}$ & $33.1^{\mathrm{d}}$ & $0.24-0.49$ \\
\hline 3 & $32.0^{\mathrm{d}}$ & $33.2^{\mathrm{d}}$ & $33.8^{\mathrm{d}}$ & $0.23-0.35$ \\
\hline 4 & $32.3^{\mathrm{c}}$ & $33.2^{\mathrm{d}}$ & $34.2^{\mathrm{e}}$ & $0.16-0.26$ \\
\hline 5 & $32.7^{\mathrm{c}}$ & $33.2^{\mathrm{c}}$ & $34.2^{\mathrm{d}}$ & $0.28-0.47$ \\
\hline \multicolumn{5}{|l|}{ Targhee } \\
\hline 1 & 30.2 & 31.9 & ND & $1.15-1.15$ \\
\hline 2 & $31.0^{\mathrm{c}}$ & $32.3^{\mathrm{d}}$ & $33.5^{\mathrm{e}}$ & $0.25-0.46$ \\
\hline 3 & $31.9^{\mathrm{c}}$ & $34.1^{\mathrm{d}}$ & $35.4^{\mathrm{e}}$ & $0.24-0.35$ \\
\hline 4 & $32.9^{\mathrm{c}}$ & $34.2^{\mathrm{d}}$ & $35.4^{\mathrm{e}}$ & $0.18-0.31$ \\
\hline 5 & $33.8^{\mathrm{c}}$ & $34.3^{\mathrm{cd}}$ & $35.0^{\mathrm{d}}$ & $0.30-0.55$ \\
\hline
\end{tabular}

aEwe's milking potential subjectively measured within $24 \mathrm{~h}$ postpartum.

${ }^{\mathrm{b}}$ Not determined because of low number of ewes.

${ }_{\mathrm{c}, \mathrm{d}, \mathrm{e}}$ Within a row, means without a common superscript letter differ $(P<0.05)$.

and individual lamb growth. In all ages and breeds, ewes with high milk scores reared heavier $(P<0.05)$ lambs than did ewes with low milk scores. Individual lamb weights from ewes with average milk scores were intermediate to weights of lambs from ewes with low or high milk scores. With increasing lactations from 1 to $3 \mathrm{yr}$ of age there was an increase in individual lamb weaning weights within all milk score classifications. Because the time period when milk production most significantly influences lamb growth occurs before 6 wk postpartum (Slen et al., 1963; Snowder and Glimp, 1991), differences between milk score groups for lamb weaning weights may have been greater if weaning were at 40 or $60 \mathrm{~d}$ rather than $120 \mathrm{~d}$.

\section{Implications}

Milk production of a ewe has an important effect on the preweaning survival and growth of her lambs. Subjectively scoring a ewe for her potential milking ability provides producers with a way to predict her ability to rear lambs successfully. Results of this study clearly show that an early postpartum, subjectively assigned milk score can be a useful management tool for deciding whether to orphan or foster lambs to improve lamb survival and growth. Improved milk scores would result in heavier lamb weights and greater total litter weight weaned per ewe lambing. Therefore, milk score should be considered for improving animal management at lambing and possibly as a selection trait to improve productive performance.

\section{Literature Cited}

Boyazoglu, J. G., and T. T. Treacher. 1978. Milk production in the ewe. In: J. G. Boyazoglu and T. T. Treacher (ed.) Proc. Sheep and Goat Commission of the European Association for Animal Production. European Association for Animal Production Publication No. 23, Brussels.

Burris, M. J., and C. A. Baugus. 1955. Milk consumption and growth of suckling lambs. J. Anim. Sci. 14:186-199.

Delouis, C., J. Djiane, L. M. Houdebine, and M. Terqui. 1980. Relation between hormones and mammary gland function. J. Dairy Sci. 63:1492-1513.

Ercanbrack, S. K., and A. D. Knight. 1998. Responses to various selection protocols for lamb production in Rambouillet, Targhee, Columbia, and Polypay sheep. J. Anim. Sci. 76:1311-1325.

Gama, L. T., G. E. Dickerson, L. D. Young, and K. A. Leymaster. 1991. Effects of breed, heterosis, age of dam, litter size, and birth weight on lamb mortality. J. Anim. Sci. 69:2727-2743.

Gibb, M. J., and T. T. Treacher. 1982. The effect of body condition and nutrition during late pregnancy on the performance of grazing ewes during lactation. Anim. Prod. 34:123-129.

Harvey, W. R. 1990. User's Guide for LSMLMW and MIXMDL PC2 Version. (mimeo). The Ohio State Univ., Columbus.

Iman, N. Y., and A. L. Slyter. 1996. Lifetime lamb and wool production of Targhee or Finn-Dorset-Targhee ewes managed as farm or range flock: I. Average annual ewe performance. J. Anim. Sci. 74:1757-1764.

LeFeuvre, A. S., and D. J. Jordan. 1979. Lambs . . why do they die? Qld. Agric. J. 105:7-10.

Neidig, R. E., and E. J. Iddings. 1919. Quantity and composition of ewes milk: Its relation to the growth of lambs. J. Agric. Res. 17:19-32.

Peart, J. N. 1968. Some effects of live weight and body condition on the milk production of Blackface ewes. J. Agric. Sci. 70:331-338.

Rattray, P. V., W. N. Garrett, N. E. East, and N. Hinman. 1974. Growth, development and composition of the ovine conceptus and mammary gland during pregnancy. J. Anim. Sci. 38:613626.

Slen, S. B., R. D. Clark, and R. Hironaka. 1963. A comparison of milk production and its relation to lamb growth in five breeds of sheep. Can. J. Anim. Sci. 43:16-21.

Snowder, G. D., and H. A. Glimp. 1991. Influence of breed, number of suckling lambs, and stage of lactation on ewe milk production and lamb growth under range conditions. J. Anim. Sci. 69:923-930.

Snowder, G. D., and A. D. Knight. 1995. Breed effects of foster lamb and foster dam on lamb viability and growth. J. Anim. Sci. 73:1559-1566.

Snowder, G. D., M. Shelton, and P. Thompson. 1986. Evaluation of Finn-cross and Rambouillet ewes under Texas range conditions. SID Res. Digest Winter:31-35.

Torres-Hernandez, G., and W. Hohenboken. 1980. Relationship between ewe milk production and composition and preweaning lamb weight gain. J. Anim. Sci. 50:597-603.

Treacher, T. T. 1983. Nutrient requirements for lactation in the ewe. In: W. Haresign. (ed.) Sheep Production. pp 133-153. Butterworths, London.

Walker, D. M., and S. G. Hunt. 1980. Effects of birth weight and energy gain preweaning on survival of lambs weaned at 21 days. Aust. J. Agric. Res. 31:981-989. 